\title{
Analysis on Three Versions of If by Life You Were Deceived from Perspective of Stylistics
}

\author{
Qiming Chen \\ Guangdong Polytechnic College, Guang zhou, China
}

\begin{abstract}
A. С. Pushkin's poem ЕСЛИ ЖИЗНЬ ТЕБЯ ОБМАНЕТ was translated into many languages for the time being, and is famous all over the world. In this article, three versions (Russian, English and Chinese) of the poem are analyzed from the perspective of stylistics, including the lexical categories, the rhythm, the rhyme, and the sentence pattern. The purpose is to help understand the language differences of this poem in Russian, English and Chinese more cleary, and to compare the two translation versions with the original, and it is an attempt to apply stylistics into the research of literature and translation as well.
\end{abstract}

Index Terms-analysis, three versions of ЕСЛИ ЖИЗНЬ ТЕБЯ ОБМАНЕТ, stylistics, translation

\section{INT RODUCTION}

The poem ЕСЛИ ЖИЗНЬ ТЕБЯ ОБМАНЕТ by А. С. Pushkin is worldly famous for the time being, and was translated into many languages. There are for instance the English version If by Life You were Deceived and the Chinese version 假如生活欺骗了你. They are respectively:

\section{Russian version:}

ЕСЛИ ЖИЗНЬ ТЕБЯ ОБМАНЕТ

Если жизнь тебя обманет,

Не печалься, не сердись!

В день уныния, смирись:

День веселья, верь, настанет.

Сердце в будущем живёт;

Настоящее уныло:

Всё мгновенно, всё пройдёт;

Что пройдёт, то будет мило.

English version

If by life you were deceived

If by life you were deceived,

Don't be dismal, don't be wild!

In the day of grief, be mild!

Merry days will come, believe.

Heart is living in tomorrow;

Present is dejected here;

In a mo ment, passes sorrow;

That which passes will be dear. (Translated by M. Kneller) ${ }^{1}$

Chinese version:

《假如生活欺骗了你》

假如生活欺骗了你,

不要忧郁, 也不要愤慨!

不顺心时暂且克制自己，

相信吧，快乐之日就会到来。

我们的心儿憧憬着未来,

现今总是令人悲哀:

一切都是暂时的, 转瞬即逝,

而那逝去的将变得可爱。 (Translated by ZHA Liang-zheng) ${ }^{2}$

A. C. Pushkin, one of the representatives of Russian Romanticism and the founder of Russian realism in literature, originally composed the poem ЕСЛИ ЖИЗНЬ ТЕБЯ ОБМАНЕТ in simple words, which made it easy to be read, understood, and memorized. The 8-line short poem reveals the poet's optimistic attitude toward setbacks or misfortunes

Note $^{1}:$ http://www.reeds.com.cn/forum.php?mod=viewthread\&tid=472, June, 2012

Note $^{2}:$ http://bbs.24en.com/hread-165079-1-1.html, June,2012 
in life. Don't be dismal, don't be wild. Be mild and believe that merry days will come tomorrow. These imperative expressions are presented in plain simple words. It gives readers the intrapersonal power to be optimistic to life and reveals the poet's despise to misfortunes, the ambition to pursue the happiness of life, the determination, and the spirit of persistence. Thus, readers who are reading the poem aloud or silently will immediately get tremendous indwelling power and reactivate themselves with vitality when they are in trouble or when they have some kind of misfortunes. Probably, that is why the poem is world-widely spreading.

Pushkin's short poem is dominantly composed of imperative expressions. Generally speaking, it is against the rule in literature writing. However, the simple style gives readers simplicity and frankness, which shortens the distance between readers and the poet and makes the poem just like a private conversation between close friends. Thus, the persuasive tone of this poem plays a good role of the interpersonal function. Therefore, the poem's popularization is achieved and deserved.

To better understand the substance of the poem and the poet's language choice as well as its English and Chinese translations, it is essential to have an analysis on the poem from more different and specific aspects. Therefore, a stylistic description on the three versions (Russian, English and Chinese) of the poem ЕСЛИ ЖИЗНЬ ТЕБЯ ОБМАНЕТ is undertaken in this article.

Every analysis of style is an attempt to find the artistic principles underlying a poet's choice of language (Leech \& Short, 2003). Any text of any writer, therefore, has its unique individual writing qualities, which can be discovered by stylistic analysis, and then it is possible to reveal the stylistic characters of the poem to help better understand the poem and its English and Chinese translations. Style can be the characteristics of the distinctive personal use of language in context, can be the selection of features partly determined by the demands of genre, form, theme, etc., can be the choice between alternative expressions, and can be the linguistic variety restricted by context.

As to the notion of style, translation theorists consider it consists of the (1 iterary) translator's choice of the type of material to translate where applicable, and his/her consistent use of specific strategies, including the use of the prefaces or afterwords, the footnotes, and the glossing in the body of the text, etc. Therefore a translators' style covers certain patterns or preferences for using specific "lexical items, syntactic patterns, cohesive devices or style of punctuation where other options may be equally available in the language" (Baker, 2000, p. 248). No matter what kind of definitions, text genre, choice of colloquial language or written language, differences of thinking and expressions, syntactical differences, tone and rhetorical differences, which are specific to an individual translator, all can be ingredients of the style of a translator. Based on this, the following analysis is made to give a relatively thorough depiction of the styles in the three versions of the poem ЕСЛИ ЖИЗНЬ ТЕБЯ ОБМАНЕТ by А. С. Pushkin.

\section{LEXICAL CATEGORIES OF THREE VERSIONS}

The first here is a comparison of lexical categories of the three versions (Fig.1). Generally, simple words or easy expressions are used in the three versions of the poem. From the Russian version, the poem was composed to a 15-year-old girl, so the simple and easy words are selected by the poet. Therefore, the simplicity of words and expressions is used to strengthen the subject and the poet's purpose. The following figures will give us a rough knowledge about the lexical categories in the three versions.

\begin{tabular}{|l|l|l|l|}
\hline & Russian version & English version & Chinese version \\
\hline total words (no punctuation) & 31 & 44 & 77 \\
\hline number of nouns & 7 & 8 & 11 \\
\hline number of verb phase & 16 & 11 & 11 \\
\hline number of empty words & 9 & 9 & -- \\
\hline metre & Stressed and unstressed syllabi alternate. & [a] [a] [a] [b] [b] [b] [a] [b] \\
\hline rhyme & {$[\mathrm{a}][\mathrm{b}][\mathrm{b}][\mathrm{a}][\mathrm{a}][\mathrm{c}][\mathrm{a}]$} & {$[\mathrm{a}][\mathrm{a}][\mathrm{a}][\mathrm{b}][\mathrm{c}][\mathrm{b}][\mathrm{c}]$} & {$[\mathrm{a}][\mathrm{b}]$} \\
\hline main sentence pattern & hypothetical condition clause, imperative, subject-predicate sent ence \\
\hline
\end{tabular}




\begin{tabular}{|l|l|l|}
\hline Russian version & English version & Chinese version \\
\hline Если & If & 假如 \\
\hline жизнь & (by) life & 生活 \\
\hline обманет & were deceived & 欺骗 \\
\hline Тебя (object) & you (subject) & 你 (object) \\
\hline Не печалья & Don't be dismal & 不要忧郁 \\
\hline не сердись & don't be wild & 不要愤慨 \\
\hline В день уныния & In the day of grief & 不顺心时 \\
\hline смирись & be mild & 克制 \\
\hline День веселья & Merry days & 快乐之日 \\
\hline верь & believe & 相信吧 \\
\hline настанет & will come & 就会到来 \\
\hline Сердце & Heart & 心 \\
\hline в будущем & in tomorrow & 未来 \\
\hline живёт & is living & 憧憬看 \\
\hline Настоящеe & Present & 现今 \\
\hline уныло & is dejected & 令人悲哀 \\
\hline Всё & & 一切 \\
\hline мгновенно & In a moment & 都是暂时的 \\
\hline всё & & (一切) \\
\hline пройдёт & passes & 转瞬即逝 \\
\hline Что пройдёт & That which passes & 而那逝去的 \\
\hline то & & \\
\hline будет мило & will be dear & 将变得可爱 \\
\hline
\end{tabular}

(Figure2) Comparison of detailed expressions

\section{A. Nouns}

1. Nouns in Russian version of ЕСЛИ ЖИЗНЬ ТЕБЯ ОБМАНЕТ

In the poem, there are only seven nouns: жизни, день, уныния, веселья, будущий, сердце, настоящий, and all these nouns are very easy to be understood even for a 15-year-old girl. Therefore, these words are used to show the general subject, the simplicity of life, and the attitude towards the affliction. Жизни (life) and Сердце (heart) are the most important parts in human's body, and what the human must experience is the sad days or happy days (день уныния или веселья). In the poem, all the sadness and happiness are included, so the poet wrote the poem aiming to reveal the truth of life.

2. Nouns in English version of ЕСЛИЖИЗНЬ ТЕБЯ ОБМАНЕТ

In the English version If by life you were deceived, there are the same nu mber of nouns as the original: life, day, grief, heart, tomorrow, present, moment, sorrow. All of the six nouns are also very simple, which are widely used in colloquial English, therefore, these words are also suitable to reveal the truth of life, and that is, life is filled with happy days and sad days. At the same time, these nouns are tangible to a 15-year girl. But one sentence is quite different from the original one: "In a moment, passes sorrow", while the original is "Всё мгновенно, всё пройдёт" which means “All is temporary and all will be gone soon".

\section{Nouns in Chinese version of ЕСЛИ ЖИЗНЬ ТЕБЯ ОБМАНЕТ}

In the Chinese version 《假如生活欺骗了你》, there are only four nouns: 生活(life), 日(day), 心 (heart), 现今 (nowadays), 未来(future), 转瞬 (moment). Some nouns in the Russian version and English version do not occur in Chinese version, for instance, уныния или веселья (sadness and happiness) are replaced by verbs “忧郁和愤慨” (means melancholy and indignant), while the most important words like life, day, future and heart are translated with their corres ponding equivalents.

From this aspect, the nouns used in these three poems serve well to express the subject of the poem, to reveal the truth of human life, and also to show the simplicity of the moral with these simple colloquial words. At this level, the three versions are equivalent to each other.

\section{B. Verbs}

1. Verbs in Russian version of ЕСЛИ ЖИЗНЬ ТЕБЯ ОБМАНЕТ

From the original poem, it is easy to find that обманет, печалься, сер дись, смирись, верь, настанет, живёт, уныло, мгновенно, пройдёт, пройдёт, будет мило are verbs, among which there are four authoritative verbs (печалься, сердись, смирись, верь), and three impersonal verbs (уныло, мгновенно, будет мило). Linguists think that authoritative verbs have a suggestive function to the listeners in daily communication, therefore, Pushkin also expected the 15-year girl to bravely face the difficulties and misfortunes of life. The impersonal verbs in this poem can give the readers an impression that something for the young is so unchangeable that people have to face and accept the ir life. In fact, with these verbs the structure of the poem is constructed. In the 30-word poem, 12 are verbs, almost half of the text. On the other hand, these verbs are also simple, either to read or to write. 


\section{Verbs in English version of ЕСЛИ ЖИЗНЬ ТЕБЯ ОБМАНЕТ}

In the 44-word English version, the poem is composed of verbs or verb phrases. Similarly, there are four authoritative verbs or verb phrases: don't be dismal, don't be wild, be mild and believe, which is equivalent to the original version. Equal to its Russian version, most of the subjects are not personal, which shows that the fortune is not controlled by people.

\section{Verbs in Chinese version of СЛИ ЖИЗНЬ ТЕБЯ ОБМАНЕТ}

In Chinese, most of sentences are generally constructed by nouns and verbs or verb phrases, so do the Chinese version of ЕСЛИ ЖИЗНЬ ТЕБЯ ОБМА НЕТ. But in the Chinese version, there are 11 verb phrases, which are equal to its English version, while in Russian version there are 16 verb phrases.

From the Russian version, it can be concluded that the verbs used in the poem are chosen carefully by the writer, which are also to show subject of that life is unchangeable and sometimes people are powerless to the fortune or misfortune. And in English and Chinese versions, the features are also realized accordingly.

4. Empty words in three versions of ЕСЛИ ЖИЗНЬ ТЕБЯ ОБМАНЕТ

In general, the empty words used in these poems are very easy to understand, even to the 15 -year girl, and their numbers are small. In the poem, the first empty word ЕСЛИ (if) plays an important role to attract the reader's eyes, to show the possibility of being cheated. Of course, in Russian, some empty words are necessary to connect the sentence, so does in English, but the empty words also play a role to show the rhythm of the poem and the rise and fall of accent.

By the way, the differences in Russian, English and Chinese are represented by these words or phrases. Firstly, the word "Тебя" is used in the Russian poem as an object, which is similar in Chinese translation, while in English the sentence is translated as a passive voice and the word "you" which is equal to "Тебя" in mean ing is used as the subject, as in English passive voice is more often used and it also realized the idea that you are doomed to be deceived sometimes, no matter how you are careful. Secondly, in Russian "обманет" is present voice and active voice, while its English version is past voice and passive voice, and its Chinese version is past voice with the word "了”, as in English subjunctive mood is used when it is hypothetical, while in Russian and Chinese, subjunctive mood is often expressed by some others' additional words instead of form change of verbs. Thirdly, “В день уныния” is translated as “不顺心时”, while it originally means “在不顺心时”, as the latter is equal to the former in Chinese and “Сердще" is translated as “心儿”, as in Chinese “儿” can be used after nouns to produce a "Rhotic accent" without changing its meaning. Fourthly, "Tо" in the original is used as a model particle, but its English translation omitted it and its Chinese translation is the adversative conjunction "而" which means "while" in the context. Therefore, in translation, the empty words are more freely changed in different languages.

\section{RHYTHM AND METRE}

Rhythm is the pattern or flow of sound created by the arrangement of stressed and unstressed syllables in accentual verse or of long and short syllables in quantitative verse $\mathrm{e}^{3}$. Metre refers to the regular pattern of stressed and unstressed syllables. (SHAO-Jingdi \& BAI-Jingpeng, 2003) Rhythm and metre are very important to the poems and widely used in poems, which make the poem full of musical sense.

Если жизнь тебя обманет,

/ $\mathrm{U} / \mathrm{U} / \mathrm{U} / \mathrm{U}$

Не печалься, не сердись!

/ U / U / U / U

В день уныния, смирись:

/ $\mathrm{U} / \mathrm{U} / \mathrm{U}$

День веселья, верь, настанет.

/ U/ U / U/U

Сердце в будущем живёт;

/ $\mathrm{U} / \mathrm{U} / \mathrm{U}$

Настоящее уныло:

/ $\mathrm{U} / \mathrm{U} / \mathrm{U} / \mathrm{U}$

Всё мгновенно,всё пройдёт;

/ U / U / U /

Что пройдёт,то будет мило.

/ U / U / U / U

(a stressed syllable is marked with "", and an unstressed syllable is marked with "U")

If by life you were deceived,

/ / U / / / U

Don't be dismal, don't be wild!

$\mathrm{U} / \mathrm{U} / \mathrm{U} / \mathrm{U}$

Note $^{3}:$ http://www.thefreedictionary.com/rhythm, June, 2012 
In the day of grief, be mild!

/ / $\mathrm{U} / \mathrm{U}$ / $\mathrm{U}$

Merry days will come, believe.

$\mathrm{U} / \mathrm{U} / \mathrm{U} / \mathrm{U}$

Heart is living in tomorrow;

$\mathrm{U} / \mathrm{U} / / \mathrm{U} /$

Present is dejected here;

$\mathrm{U} /$ / / U /

In a moment, passes sorrow;

/ $\mathrm{U} / \mathrm{U} / \mathrm{U} /$

That which passes will be dear.

$\mathrm{U} / \mathrm{U} /$ / U

假如生活欺骗了你,

$\mathrm{U} / \mathrm{U} / \mathrm{U} / \mathrm{U}$

不要忧郁, 也不要愤慨!

/ U/U // U UU

不顺心时暂且克制自己,

/ U// U/ U/U /

相信吧, 快乐之日就会到来。

/ U/ U/ / U U/ U/

我们的心儿憧憬着未来,

$\mathrm{U} / / \mathrm{U} / \mathrm{U} /$ / U /

现今总是令人悲哀:

$\mathrm{U} / \mathrm{U} /$ / $\mathrm{U}$ /

一切都是暂时的, 转瞬即逝,

/ $\mathrm{U} / \mathrm{U} \mathrm{U} /$ / / $\mathrm{U}$

而那逝去的将变得可爱。

/ U U/ / U / / U

Accordingly, the original, the English version and Chinese version all have the same kind of rhythm and metre.

\section{RHYME}

Rhyme is the repetition of the stressed vowel and all succeeding sounds. (SHAO-Jingdi \& BAI-Jingpeng, 2003) Rhyme is very important to poems, and widely used in poems, in which end rhyme is the commonest and most consciously sought-after sound repetition in poetry. In the three versions of ЕСЛИ ЖИЗНЬ ТЕБЯ ОБМАНЕТ, the end rhyme is used with different patterns.

\section{A. Rhyme of Russian Version}

In Russian version of the poem, the end rhyme is obvious: the first, fourth, fifth and seventh sentences end with т, roughly equal to English symbol t, while the second and third end with ись, sixth and the last end with ло. In Line 2 and 3, the former parts end with " $я$ " (/ja/) while the latter parts end with "сь" (/si/), and in reading it, the tone rises at the beginning and falls in the end. In the last two lines, the tone rises, falls, falls and rises. According to the phonetics, the symbol $\mathrm{T}$ is a stop, which gives the readers a feeling of shortness.

ЕСЛИ ЖИЗНЬ ТЕБЯ ОБМАНЕТ

Если жизнь тебя обманет,

Не печалься, не сер дись!

В день уныния, смирись:

День веселья, верь, настанет.

Сердце в будущем живёт;

[a]

Настоящее уныло:

[a]

[c]

Всё мгновенно, всё пройдёт;

[a]

Что пройдёт, то будет мило.

[c]

\section{B. Rhyme of English Version}

Though the rhyme in English version of the poem is not the same as that in Russian version, the end rhyme d is also a stop, and the rhyme of its English version is also carefully used:

If by life you were deceived

If by life you were deceived,

Don't be dismal, don't be wild!

In the day of grief, be mild 
Merry days will come, believe.

Heart is living in to morrow;

Present is dejected here;

[b]

In a moment, passes sorrow;

That which passes will be dear

In the English version, it can be found that the rhyme pattern is [a] [a] [a], [b] [c] [b] [c], which is popular in English poems.

\section{Rhyme of Chinese Version}

In the translation of poems, it is difficult to translate according to their rhyme, especially at the level of phonetics, therefore, the stop $t$ is replaced by a vowel $\mathrm{i}$, but the Chinese version of the poem is not only translated according to rhyme, but also translated with two end rhymes.

《假如生活欺骗了你》

假如生活欺骗了你,

不要忧郁，也不要愤慨！

(ni) [a]

不顺心时暂且克制自己，

(kai) [b]

相信吧，快乐之日就会到来。

(ji) $\quad[\mathrm{a}]$

我们的心儿憧憬着未来,

(lai) $\quad[\mathrm{b}]$

现今总是令人悲哀:

(lai) [b]

(ai) $\quad[\mathrm{b}]$

一切都是暂时的, 转瞬即逝, (si) [a]

而那逝去的将变得可爱。

(ai) $[\mathrm{b}]$

From the comparison of the English and Chinese versions with the original Russian version, it is easy to find that the rhyme is similarly used and the two translations have expressed the features of the original rhyme.

\section{SENTENCE PATTERN}

Sentence pattern plays an important role in the literary text, and different patterns may express the writers' different subjects and aims. So the sentence pattern is also worthy of discussion.

From the original Russian poem, it can be found that there are hypothetical condition clause (the first line), imperative (the second, the third, second part of the forth line), subject-predicate sentence (part of the forth, the fifth, the seventh, and part of the last line), non subject sentence (the sixth line, part of the seventh and eighth). Hypothetical condition clause introduces the topic and attracts the reader's eyes, and it also to make readers stay calm to the situation which may not be true in real life, and the imperative sentence pattern has a feeling of suggestion, advice or wish, while non-subject sentence can give readers a feeling that all the misfortune can be solved by fortune itself.

The English and Chinese versions are also mainly made up of hypothetical condition clause, imperative, subject-predicate sentence, which play the same functions of expressing the subject and aim of the poet. Thus the two translation versions are transferred beautifully.

\section{CONCLUSION}

Through the stylistic analysis of A. C. Pushkin's poem ЕСЛИ ЖИЗНЬ ТЕБЯ ОБМАНЕТ and its English and Chinese versions from the aspects of lexical categories, rhythm, rhyme and sentence pattern, it is then concluded that the three versions are approximately equal in noun number, verb number, rhythm, rhy me and sentence pattern, and are similar in style.

Then, from the perspective of stylistics it is safe to say that the two translated versions of ЕСЛИ ЖИЗНЬ ТЕБЯ ОБМАНЕТ are to some degree equivalent to the original poem and both of the translations of English and Chinese have been done very well because all of the three texts bear nearly the same linguistic features as each other. To make it further, both of the translations play the same interpersonal role in readers as the Russian one of A. C. Pushkin. However, equivalence in translation is a complicated term which need s more research. For example, culture differences may cause opposite effects and brings about problems, which determines the translation strategies. So, this article is just an explicit demonstration for that stylistics can be effectively applied into the discovery of the linguistic features of a text. To be further, stylistics can be an effective approach to literature critic is $\mathrm{m}$ and trans lation studies as well.

\section{REFERENCES}

[1] Baker, Mona. (2000). Towards a Methodology for Investigating the Style of A Literary Translator [J]. Target, 12(2): 241-265.

[2] Carter, R. \& Simpson, P. (1989). Language, Discourse and Literature: An Introduction Reader in Discourse Sty listics. London: Unwin Hyman: 233-257.

[3] Cummings, M \& Simmons, R. (1983). The Language of Literature: A Sty listic Introduction to the Study of Literature. Oxford: Pergamon Press.

[4] Leech, G. N \& Short, M. H. (2003). Style in fiction: A Linguistic Introduction to English Fictional Prose. Pearson Education 
Limited \& Foreign Langu age Teaching and Research Press: 119-146.

[5] SHAO-Jingdi \& BAI-Jin gpeng. (2003). An Introduction to Literature. Shan ghai: Shan ghai Foreign Lan guage Education Press: 351-360.

[6] Zhanzi, Li. (2002). Interpersonal Meaning in Discourse, Shan gh ai: Shan ghai Foreign Lan guage Press: 124-175.

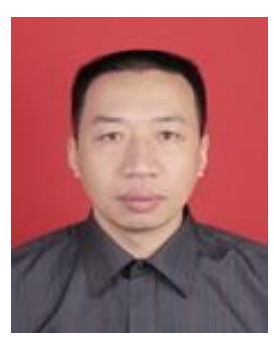

Qiming Chen was born in Chongqing, China in 1971. He received his master degree in literature from Chongqing Normal University, China in 2009.

$\mathrm{He}$ is currently a lecturer in Guangdong Polytechnic College, Guangzhou, China. His research interests include literature criticism, translation studies, and English language teaching. 